\title{
Analogous Spaces: An Introduction to Spatial Metaphors for the Organization of Knowledge
}

\author{
Wouter Van Acker And Pieter Uyttenhove
}

\section{Spatial Metaphors for the Organization OF INFORMATION}

Spatial metaphors abound in the language we use to speak about the organization of information. Well-established notions such as "architecture of databases," "knowledge architect," or "information design" convey their meaning by drawing analogies between the organization of information and the organization of space. The notion "architecture of databases," for example, relies on the idea that a database provides us, like a building, multiple spaces where we can position different objects that we can exploit for different functions. Just as a building is a fixed construction, the interior of which can be furnished and refurbished time and again, we can add or remove objects of knowledge or data in the categories of a database. A "knowledge architect" is another example. Through metaphor, this notion defines the job of someone who, like an architect, combines technical and artistic skills and who is able to coordinate the overall construction process; not for the purpose of constructing a building but for constructing tools to manage flows of knowledge or relevant information that is meant to remain in place (Tonfoni, 1998). "Information design" is a third example. It underscores metaphorically the idea that the development of an information system involves, as is the case in design, a complex process of planning before actual construction can occur. Furthermore, one applies the word "design" to information systems to imply that they are modeled in a smart way, to minimize the user's efforts and to do so in respect to his or her personal needs.

In the field of architectural and urban design, on the other hand, a growing number of metaphors have been borrowed from information and system theory. Leading architects have absorbed into their discourse concepts such as cybernetics, chaos theory, complexity, and self-orga- 
nizing or nonlinear dynamic systems. They build architectural forms by means of computer-aided design and choose, analogous to the way we search for and select information, the final form of their design as a crosssection taken from a continuous flow of animated, digital forms and their geometrical transformations (Picon, 2003). Moreover, prominent urban designers conceptualize the city's complexity in terms of information, communication, and computerization. Information-in the way in which it flows around the world, lacks overview, and constitutes a dynamic archive-is used by urban planners to pinpoint the dynamic, mutating character of the contemporary city (Boyer, 2011).

Borrowing concepts and images from architectural and urban design to develop a new way of understanding library and information science (LIS) concepts is not a recent phenomenon. The interpretation of information as the organization of space, and space as the organization of information, has a rich history. Examples include the art of memory in Roman times, the memory theaters of the Renaissance, novels that build their narrative around fictional spaces, the way in which churches spatially translate the narratives of the bible, or the cabinets of curiosity and the universal exhibitions that were conceived as comprehensive encyclopedias.

The long list of metaphors that we use to conceptualize information and knowledge can be explained by the creative and explanatory powers of metaphors and analogies, which are, in turn, directly linked to their capacity to transfer concepts among fields of knowledge. The creative and explanatory nature and use of metaphors and analogies in the sciences have been documented in a considerable amount of literature (van Noppen, 1985; van Noppen \& Hols, 1990; Maasen \& Weingart, 2000). ${ }^{1}$ In general, scholars seem to agree that we use metaphors to deal with phenomena or concepts for which we still lack precise descriptions. ${ }^{2}$ Metaphors function on the basis of analogy or the similarity that exists between two or more apparently dissimilar things. By means of analogies or approximating resemblances, metaphors help us to see or identify things as something else, and thus prepare the way for a new and more adequate interpretation (Ricoeur, 1986, p. 243). Through analogy or expression of similarities between what is dissimilar, metaphors allow "creative mental leaps" to be made (Holyoak \& Thagard, 1995, p. 223).

Metaphors and the analogies they establish function by transferring information from a "source domain" (which is used as a means of interpretation or explanation) to a "target domain" (which is to be interpreted or explained) (Vosniadou \& Ortony, 1989, p.6). Such a transfer may occur between different scientific disciplines, but it also can occur between everyday discourse and specialized discourse. In other words, metaphors may operate as interfaces in both intrascientific and extrascientific domains (Bono, 1990, p. 59-89). During that transfer, our understanding of both the source and the target changes. Not only do metaphors change 
the literal meaning of the target domain because of the newly associated ideas (Black, 1962; Hesse, 1966, p. 163), but the associations that are established with the target domain affect in turn the source domain through assimilation. During that interaction and adaptation of source to target and vice versa, both the language of description and explanation itself have been redescribed according to our new insights.

Moreover, metaphors and analogies usually do not rely on the transfer of a single predicate but instead on the transfer of an entire realm or field of concepts. This is certainly true for the cases studied in this volume. To speak of the architecture of the book or the database, for example, is to bring the entire realm of architecture into the territory of LIS. A conceptual migration takes place from a domain of origin (architecture) to a domain of adoption (LIS). During this transfer, the use of the field of concepts (e.g., stability, structure, symmetry, orientation, etc.) in the domain of origin provides guidance to their use in the new domain of application. The major interest of such metaphorization is the heuristic power that comes with describing and redescribing a lesser-known concept in the light of a better-known experience or insight. In this regard, the phenomenological dimension of architecture (the experience and the structuring aspect of spaces in our daily lives) as well as the visual instruments of architecture (plan and mapping techniques) are important reasons why architecture is often used as a metaphorical explanans in LIS.

This brings us to the central theme of this issue: The inherently visual, spatial, and experiential nature of metaphors and analogies that we believe makes architectural metaphors particularly powerful, especially in relation to the organization of knowledge. Metaphors ensure the mediative service of bridging (besides interdisciplinary gaps) the domains of reason and the senses. In other words, they link concepts and images. Thinking through metaphors is a kind of picture-thinking or a way of seeing something as something else. According to Hester, the metaphorical "seeing as" is "an intuitive experience-act by which one selects from the quasi-sensory mass of imagery one has on reading metaphor the relevant aspects of such imagery" (Hester, 1967, p. 180; Ricoeur, 1986, p. 212). A metaphor places analogies before the eyes, with the result that concept and image, what is thought and what is sensed, are united. Through a mediating image, abstract relations are suddenly made concrete; what is dissimilar is visually imagined to be similar; and what is discordant is revealed to be concordant (Stafford, 1999). Bachelard has pointed out that "images and concepts are formed at opposite poles of mental activity: imagination and reason" (Bachelard, 1987, p. 7) but also that images seduce conceptual reason and distort the stability of its system. Not coincidently, explorative and intuitive thinking is guided by images, by an associative method, and by establishing analogies between what is seemingly incongruent. 
The explanatory power of images that "occur" in, and guide the quasi experience of, the metaphorical moment results from their concreteness, which is rooted in our lived experience. Therefore, spatial images and concepts are particularly persuasive as vehicles that firmly link the sensible to the logical moment of metaphor. Metaphors are, as Lakoff and Johnson call them, concepts that "we live by"; they are not just linguistic expressions but concepts through which we understand and act in the world, and they result from the way in which we do so (Lakoff \& Johnson, 1980). According to the proponents of embodied cognition such as Mark Johnson, metaphorical understanding is an imaginative understanding of one thing in terms of another that is grounded in the interactions with our physical and cultural environment (Johnson, 1987; Pinker, 1989). Because metaphors allow us to grasp more abstract concepts by mobilizing concepts with which we are familiar in terms of our experience, it comes as no surprise that we often use spatial experiences to explain and structure particular insights or statements about abstract notions such as, in the case of this issue of Library Trends, knowledge or information. We compare theories to buildings when we speak of the "foundations" of a theory or the "solidity" of an argument; and we give spatial orientations of "up" and "down" to various concepts, such as consciousness, control, or hierarchy (e.g., in phrases such as "get up," "have control over," or "climb the social ladder") (Lakoff \& Johnson, 1980). Spatial structures that we register when we move within our (built) environment and observe the location and movement of objects and people can be mapped onto analogous nonspatial and abstract structures of elements or concepts (Gattis, 2001, p. 2-7).

\section{Analogous Spaces}

This analogy between spatial and conceptual structures is the modus operandi of what we would like to call analogous spaces. Analogous spaces are those spaces that are used for mapping either real, experiential, and material objects (e.g., buildings, towns, works of art, and archives) or virtual, abstract, and immaterial data, concepts, or elements of information (e.g., scholarly communication, documentation, audiovisual environment, Internet, and scientific data). Analogous spaces are mental architectures responding to a similar relational structure that serves the ordering and organization of different types of knowledge, memory, or action. In analogous spaces, knowledge can be preserved, organized, transferred, or activated. While they may differ in operational ways, their "analogous" character derives not only from the analogies they establish "vertically" between real spaces and information structures but also from their "horizontal" coexistence and similarities.

Analogous spaces resemble each other or are analogous in terms of their "structure," "form," and "architecture." As such, they are devices of 
innovation that discover and create connections not only between the real world and the world of thought but also between the different fields of thought. Analogous spaces may serve different cognitive purposes such as communication, memorization, and decision making. In accordance with these purposes, three types of analogous spaces may be identified: diagrammatic, mnemonic, and action spaces. By the first type, diagrammatic spaces, we refer to spaces that express and visualize and that therefore enable us to conceptualize complex relations between elements. Diagrams of social and intellectual networks, for example, use different network models to reflect on the development and effectiveness of the geographic relationships between people and assist in understanding their formation, evolution, and dissolution. By mnemonic spaces, we allude to spaces that use architecture as an archival means for storing and structuring historic data or archival elements, setting and holding them in place, and providing routes of access to and between them. An example of this second type of analogous space is the memory building through which the ancient orator, following the method of the loci in the Greek art of memory, imagined he moved while making his speech, drawing from the memorized places the images he had placed on them (Yates, 1966, p. 18). By the third type, action spaces, we refer to spaces that help people to make decisions and take action through rapid and efficient monitoring tools and expert systems that enhance organization, intelligence, and feedback. Surveys in the field of town planning, for example, are information spaces that not only amass extensive knowledge about the city but also synthesize and organize it in a goal-oriented way in order to be able to facilitate urban planning. Speed of information processing becomes a strategic dimension in these spaces of action and decision making.

\section{International Conference on Analogous Spaces, GHent University, 2008}

We publicized and continued to define the term "analogous spaces" in 2008 at the International Conference on Analogous Spaces on May 14 to 17, 2008, at the Museum of Fine Arts in Ghent. The conference was jointly organized by the Department of Architecture and Urbanism, the University Library, and the Department of Telecommunications and Information Processing of Ghent University. It opened on May 14 with a lecture by Floris Alkemade, replied to by Rolf Hughes, about the role of diagrams and metaphors in the design and research of OMA/AMO, the Office for Metropolitan Architecture and its mirror studio for research, branding, and publication. During the conference, forty-one papers were delivered on the three types of analogous spaces outlined here earlier. Many of the presentations can be downloaded from the conference webpage (http://www.analogousspaces.com/Presenters). A Paul Otlet Study Tour on May 17 and 18 concluded the conference. 
The 2008 conference in Ghent was the third in a series of international scholarly gatherings. In May 2002, an international symposium, Architecture of Knowledge-The Mundaneum and European Antecedents of the World Wide Web, was held at the Mundaneum in Mons (Belgium), the museum and documentation center where the archives of the Belgian bibliographer and visionary internationalist Paul Otlet (1868-1944) are conserved (van den Heuvel et al., 2003). In May 2005, an international colloquium, European Modernism and the Information Society, was held at The Graduate School of Library and Information Science, University of Illinois at Urbana-Champaign (Rayward, 2008). All three gatherings emphasized the spatial and historical dimensions of information as central points of interest. It is also worth mentioning here that Google has shown interest in these matters. Ghent University Library became a partner of the worldwide Google books digital project, and the Mundaneum and Ghent University recently started a partnership with Google focusing on Paul Otlet's visionary ideas on worldwide connectivity and access to documentation.

At the analogous-spaces conference, the visualizations of Paul Otlet were brought to the attention of the scholarly community as a special case study. Otlet's work is a milestone in the history of information science and has been since he launched the concept of "documentation," a field that evolved from bibliography and eventually developed into information science (Rayward, 1975, 1994, 2008). Today, Otlet is a well-known figure in the history of information science and is often made trendy by journalists who depict him in presentist terms as the forgotten forefather of the World Wide Web or search engines such as Google (Wright, 2008; Djian, 2009). The visionary character of his work is one of the reasons why the work of Otlet continues to fascinate. Although Otlet's schemes were and are often criticized for their megalomania and apparent naiveté, they also reveal the extraordinary sense of organizational imagination with which he was gifted (Van Acker, 2011). Presented through exhibitions, pamphlets, articles, and lectures, the large collection of drawings that he produced throughout his life helped him to marshal his thoughts about the organization of documentation and information. They also served as publicity tools, maintaining the visibility of Otlet's internationalist ideas and projects, not in the least, the International Museum occupying the prestigious Palais du Cinquantenaire in Brussels. At the same time, he assembled his schemas in a visual educational encyclopedia, called the Encyclopedia Universalis Mundaneum, which was a notable experiment in encyclopedic documentation against the background of the longstanding research of the International Institute of Bibliography, which he directed with Henri La Fontaine. The visualizations of Otlet are a useful stepping stone to this issue of Library Trends, as the visual language that they use is characteristically metaphorical. The images or figures in his schemas 
function as metaphors in that they represent abstract or nontangible ideas about the organization of information by means of spatial structures and more figurative associations and comparisons.

The nine articles that follow, three of which are devoted to the visualizations of Otlet, are drawn from the presentations read at the analogousspaces conference. They are the result of a rigorous process of selection and review. They all delve into the rich history of metaphorical or analogical relations between the domain of LIS and architecture. Both architectural historians and historians of LIS have contributed to this issue. In most contributions, the authors build on their expertise acquired in their own disciplinary field, but they also engage in a transdisciplinary practice. In that practice they abandon disciplinary mastery and oversight, and take a closer look at moments when translation and transfer of concepts and techniques occur across disciplinary borders.

\section{Overview}

The first cluster of articles are concerned with spatial figures that are used to visualize and metaphorize conceptual structures of knowledge organization. These are led by Michael Buckland's answer to the question of why spatial analogies are so widely used in language and imagery relating to librarianship, documentation, and information science. Starting from a definition of analogy as a structural, exploratory, or argumentative figure based on selective similarity, Buckland examines in the work of leading innovators of knowledge organization, notably in the work of Paul Otlet, the use of notions of space, place, location, and movement. While some examples of Otlet's spatial analogies are found to be traditional and conventional, other spatial images about information and information systems are found to be original and thoughtful. Thomas Hapke documents how the chemist and Nobel laureate Wilhelm Ostwald used combinatorics as an analogous, creative, and interdisciplinary way of thinking in knowledge organization and in his theory of colors and forms. Based on his activities in chemistry and his philosophy of nature, Ostwald believed that the exploration of relations and analogies between basic concepts could lead to the discovery and creation of new complex concepts. With spatial analogies like a bridge, net, or pyramid, he illustrated, Hapke argues, that combinatorial thinking was a tool to improve the organizational form of information and a support to build bridges between scholarly disciplines. The article by Guy De Tré and Wouter Van Acker discusses from a computer scientist's point of view the analogies and links between Otlet's knowledge spaces and current digital spaces for classifying, filing, and handling information. Otlet's conceptual proposals for a "universal book" and a "universal network of documentation" are shown by means of his spatial visualizations to have more in common than one would think with modern information- and knowledge-management techniques. The 
applicability and potential of Otlet's ideas are identified and explored in the light of challenges and problems that are driving new developments in information and knowledge management.

A second group of articles are devoted to the "architecture" of the book and to books that have been conceived and represented as buildings. Pierre Delsaerdt scrutinizes the typographic "architecture" of three Dutch dictionaries published by the Antwerp printer Christophe Plantin and compiled by Cornelis Kiliaan (ca. 1530-1607). The ability of these "book architects" to arrange the space of linguistic knowledge so as to guide the reader in his search for a definition or a translation is demonstrated in their accuracy in composing the text, with its alternation of black-letter, roman, and italics and the consistent application of indentation. Through their carefully considerate design of what Delsaerdt calls the "micro- and macrostructures" of the three-dimensional "space" of the codex, Kiliaan, Plantin, and Joannes Moretus are shown to have set a high standard for the retrieval of linguistic knowledge. Willem De Bruijn explores the analogy between the book and the theatre building suggested in the title of Heinrich Khunrath's theosophical treatise Amphitheatrum Sapientiae Aeternae $(1595,1609)$. By examining the architectural qualities of the book, the article speculates that the term "amphitheatre" in the title might be understood as referring to a spatial and material rather than a literary construction. The execution of the copper-plate engravings and the use of marbled paper for the end leaves are evidence of the architectural way in which the book was conceived. Like a theatre, Khunrath's printed book was literally constructed as a "seeing place," as a "stage" and backdrop for the performance of the act of reading. Wouter Van Acker's article unravels how the Belgian modernist architect Maurice Heymans translated Otlet's book Monde (1935) metaphorically into a complex architectural building, called the Mundaneum. In three previously unknown and highly detailed designs of the Mundaneum, similar in many ways to the plans made by Le Corbusier in 1928, two operative modes of analogical reasoning and visual thinking are detected: the art of memory and utopia. By designing the structure of Monde as a utopian memory theatre, Heymans made an architectural configuration analogous to the knowledge schemes proposed by Otlet.

Complementing the second group of articles, the third group is concerned with the "reading" of buildings as books and how architecture can be analogized as texts. Maarten Delbeke and Anne-Françoise Morel examine how the representational space of sixteenth- and seventeenth-century guidebooks of Rome functioned as a virtual analogue to the composite urban reality of Rome. By studying the rearrangement of their sections, illustrations, and descriptions in this period, Delbeke and Morel show how they reflected new ways of thinking about the identity of Rome and in particular the frictions between the three analogous cities of Rome: ancient, 
Christian, and modern Rome. By selecting and rearranging real as well as imaginary aspects of the three analogous Romes, successive authors and publishers attempted through the mediation of the guidebook to fit the well-known categories of the imaginary cities onto reality. Stephen Kite's article is devoted to the rich analogies and metaphors between reading and building in John Ruskin's The Stones of Venice (1851-1853). The city of Venice is for Ruskin a bewilderingly complex and sacred palimpsest where buildings are "analogized" as texts and therefore is to be "read" through a kind of Lectio Divina or divine reading. The Stones of Venice not only offers multiple patient and insightful readings of the urban fabric, which deconstruct the palimpsest-like surfaces of Venice, but also rebuilds these as literary spaces. Working with the primary notebooks, worksheets, and diaries of Ruskin, Kite examines the erection of the manuscript of The Stones, its near-Biblical exegesis of architecture, and its literary reconstruction of the city in themes of metaphor, memory, and material. Alistair Black and Simon Pepper narrate how public libraries in Britain have evolved from "civic places" in the past to "digital spaces" in the present. Assuming that library buildings, like books, can be "read" and that their meanings can be defined and debated, Black and Pepper analyze how the public library built form has been analogous to social form over the past century and a half. By adopting the theoretical lenses of Gramsci, Habermas, and Popper and by pointing out how public libraries reflect social aspirations, needs, and values, an alternative is offered for the typical controlling discourse about public library buildings. While public libraries may determine people's behavior and society, the article shows how they are also determined by people and society.

In this brief introduction, we have tried to give the reader a sense of the heuristic power and visual nature of metaphors and analogies, the background of the variety of presentations and interdisciplinary perspectives being presented, and a synopsis of the contents of this issue. We wish to thank the contributors for their great patience and their readiness to abandon at times familiar disciplinary grounds. They offer their readers the opportunity to discover and come to grips with a wide range of analogies and metaphors that we hope will open up new horizons to them, to the same extent that our authors have helped broaden our minds while preparing this volume.

\section{Appendix: International Conference On Analogous Spaces, Ghent University, May 14-1 7, 2008}

As noted, this issue of Library Trends has arisen from the interdisciplinary conference Analogous Spaces: Architecture and the Space of Information, Intellect, and Action at Ghent University, Belgium, May 14-17, 2008. The following organizational details about the conference are provided for the historical record. We wish to thank the scientific committee for 
their guidance, insights, and review of abstracts; and Sylvia Van Peteghem and her team of Ghent University Library for their indispensable support in organizing the conference, seeking funds, and designing the website.

\section{Organizing Committee}

Pieter Uyttenhove, professor, Department of Architecture and Urban Planning, Ghent University

Wouter Van Acker, postdoctoral research assistant, Department of Architecture and Urban Planning, Ghent University

Guy De Tré, professor, Department of Telecommunications and Information Processing, Ghent University

Sylvia Van Peteghem, head, Ghent University Library

\section{Scientific Committee}

Alistair Black, professor, Graduate School of Library and Information Science, University of Illinois at Urbana-Champaign

Koos Bosma, professor, Department of Art History, Vrije Universiteit Amsterdam

Pierre Chabard, professor, Ecole d'architecture de Paris-La Villette, Paris

Pierre Delsaerdt, professor, Department of Library and Information Science, University of Antwerp

Stephan Drescher, programmer R\&D, Mexican Consulate in Aarhus

Steffen Ducheyne, professor, Centre for Logic and Philosophy of Science, Vrije Universiteit Brussel

Bernd Frohmann, professor, Faculty of Information and Media Studies, University of Western Ontario

W. Boyd Rayward, professor emeritus, Graduate School of Library and Information Science, Urbana Champaign

Gert Morreel, postdoctoral researcher, Department of Library and Information Science, University of Antwerp

Dominique Rouillard, professor, Ecole d'architecture de Paris-Malaquais

Stéphane Vanbeveren, directeur du Service Architecture, Université Libre de Bruxelles

Charles van den Heuvel, head, Research History of Science, Huygens Institute for the History of the Netherlands, The Hague

David Vanderburgh, professor, Unité d'Architecture et d'Ingénierie architecturale, Université Catholique de Louvain

Herbert Van de Sompel, leader, Digital Library Research and Prototyping Team, Research Library, Los Alamos National Laboratory, New Mexico

Nader Vossoughian, professor, History and Theory of Architecture, New York Institute of Technology

Christophe Verbruggen, professor, Department of Modern History, Ghent University

Hans Van de Voorde, professor, Department of Modern History, Vrije Universiteit Brussel 


\section{Administrative and Financial Support}

The conference organizers are also grateful for the support received from the following: Ghent University; Ghent University Library; Department of Architecture and Urban Planning, Ghent University; Mundaneum; Ex Libris; J. Story-Scientia; Swets; Vitra; IBBT; Stad Gent; Stad Middelkerke; Gent Congres.

\section{Notes}

1. van Noppen has compiled two bibliographies of studies on metaphors between the $1970 \mathrm{~s}$ and 1990 (van Noppen, 1985; van Noppen \& Hols, 1990). For an overview of competing theories of metaphors-pragmatic, semantic, and constructivist-see Maasen (1995) and Maasen and Weingart (2000).

2. For the sake of simplicity, we leave aside here the concept of "model" and limit the discussion to metaphors and analogies. Models are generally assumed to be bound to the realm of science. Or, as Paul Ricoeur noted, "Metaphor is to poetic language what the model is to scientific language" (Ricoeur, 1986, p. 240).

\section{REFERENCES}

Bachelard, G. (1987). On poetic imagination and reverie: selections from Gaston Bachelard. Dallas, TX: Spring Publications.

Black, M. (1962). Models and metaphors: Studies in language and philosophy. Ithaca, NY: Cornell University Press.

Bono, J. J. (1990). Science, discourse, and literature. The role/rule of metaphor in science. In S. Peterfreund (Ed.), Literature and science: Theory E practice (pp. 59-89). Boston: Northeastern University Press.

Boyer, M. C. (2011). The two orders of cybernetics in urban form and design. In T. Banerjee \& A. Loukaitou-Sideris (Eds.), Companion to urban design (pp. 70-83). London: Routledge.

Djian, J.-M. (2009, December 19). Le Mundaneum, Google de papier. Le Monde Magazine. Retreived July, 25, 2012, from http:/ / www.mundaneum.be/fichiers/091219artlemonde.pdf

Gattis, M. (2001). Spatial schemas and abstract thought. Cambridge, MA: MIT Press.

Hesse, M. B. (1966). Models and analogies in science. Notre Dame, IN: University of Notre Dame Press.

Hester, M. B. (1967). The meaning of poetic metaphor. The Hague: Mouton.

Holyoak, K. J., \& Thagard, P. (1995). Mental leaps: Analogy in creative thought. Cambridge, MA: MIT Press.

Johnson, M. (1987). The body in the mind: The bodily basis of meaning, imagination, and reason. Chicago: University of Chicago Press.

Lakoff, G., \& Johnson, M. (1980). Metaphors we live by. Chicago: University of Chicago Press.

Maasen, S. (1995). Who is afraid of metaphors? In S. Maasen, E. Mendelsohn, \& P. Weingart (Eds.), Biology as society, society as biology: Metaphors (pp. 11-35). Dordrecht, The Netherlands: Kluwer Academic.

Maasen, S., \& Weingart, P. (2000). Metaphors and the dynamics of knowledge. London: Routledge.

Picon, A. (2003). Architecture, science, technology, and the virtual realm. In A. Picon \& A. Ponte (Eds.), Architecture and the sciences: Exchanging metaphors (pp. 292-313). New York: Princeton Architectural Press.

Pinker, S. (1989). Learnability and cognition: The acquisition of argument structure. Cambridge, MA: MIT Press.

Rayward, W. B. (1975). The universe of information. The work of Paul Otlet for documentation and international organisation. Moscow: VINITI.

Rayward, W. B. (1994). Visions of Xanadu: Paul Otlet (1968-1944) and hypertext. JASIS, 45, 235-250.

Rayward, W. B. (2008). European modernism and the information society: Introduction. In W. B. Rayward (Ed.), European modernism and the information society: Informing the present, understanding the past (pp. 1-25). Aldershot, England: Ashgate. 
Ricoeur, P. (1986). The rule of metaphor. Multidisciplinary studies of the creation of meaning in language. London: Routledge \& Kegan Paul.

Stafford, B. M. (1999). Visual analogy: consciousness as the art of connecting. Cambridge, MA: MIT Press.

Tonfoni, G. (1998). Information design: The knowledge architect's toolkit. Lanham, MD: Scarecrow Press.

Van Acker, W. (2011). Universalism as utopia. A historical study of the schemes and schemas of Paul Otlet (1868-1944).Unpublished doctoral dissertation, Ghent University.

van den Heuvel, C., Rayward, W. B., \& Uyttenhove, P. (2003). L'architecture du savoir. Une recherche sur le Mundaneum et les précurseurs européens de l'Internet. Transnational Associations, 2-3, 16-28.

van Noppen, J.-P. (1985). Metaphor. Bibliography of Post-1970 publications. Amsterdam: John Benjamins Publishing Company.

van Noppen, J.-P., \& Hols, E. (1990). Metaphor II. A classified bibliography of publication, 1985 to 1990. Amsterdam: John Benjamins Publishing Company.

Vosniadou, S., \& Ortony, A. (1989). Similarity and analogical reasoning. Cambridge, England: Cambridge University Press.

Wright, A. (2008, June 17). The Web time forgot. New York Times. Retreived July 25, 2012, from http:/ /www.nytimes.com/2008/06/17/science/17mund.html?_r=1\&pagewanted=all

Yates, F. A. (1966). The art of memory. London: Pimlico, 1992.

Pieter Uyttenhove is full professor in the Department of Architecture and Urban Planning of Ghent University, where he is currently head of department. He was trained as an engineer-architect at the University of Leuven (1980), studied urban planning at the Institut d'Urbanisme de Paris (1982), and received his doctorate in art history at the Ecole des Hautes Etudes en Sciences Sociales (EHESS) in Paris (1999). He is director of doctoral research in theory and history of urban planning, codirector of the Research Laboratory for Urban Design, Labo S, and founder of Studio Open City. He has published extensively in international journals and magazines. Among other books, he is editor of Recollecting Landscapes (2006), and author of Marcel Lods: action, architecture, histoire (2009), Stadland België (2011), and Beaudouin et Lods (2012).

Wouter Van Acker is a postdoctoral researcher at the Department of Architecture and Urban Planning at Ghent University. He earned his civil engineering/architecture degree from Ghent University in 2004. For his doctoral dissertation (PhD, civil engineering/architecture, Ghent University, 2011), he studied the visionary schemes and schemas of the Belgian internationalist and encyclopedist Paul Otlet (1868-1944). His current research focuses on the spatial organization, representation, and dissemination of information and knowledge in urban settings. 